\title{
Phytochemical and Antioxidant Activities of Different Fractional Extracts of Alstonia scholaris Linn
}

\author{
Md Abdul Kaium Siddiki and Md Shahidul Islam* \\ Department of Pharmacy, University of Science and Technology Chittagong (USTC), Bangladesh
}

*Corresponding author: Md Shahidul Islam, Department of Pharmacy, University of Science and Technology Chittagong (USTC), Chattogram, Bangladesh

\begin{abstract}
Alstonia scholaris Linn is popularly known as the "Chatim" or the Devil tree, which are used as a well-known remedy for the treatment of various types of disorders in the Ayurvedic, Homoeopathic and Folklore system of medicine in Bangladesh, India and many others countries. Alstonia scholaris is mainly used for the treatment of diarrhoea and malaria as a tonic, febrifuge, emmenagogue, anticholeric and vulnerary. Considering the medical importance and source of origin, the plant Alstonia scholaris has been subjected for fractionation with different solvents. The different fractions of ethanolic extract of Alstonia scholaris were evaluated for antioxidant activity as well as biological activity. Phytochemical properties of leaves of Alstonia scholaris were also investigated. The different solvent fractions showed the presence of tannins, glycosides, steroids, and alkaloids. The different fractions of ethanolic extract of Alstonia scholaris were evaluated for the total phenolic content, total flavonoid content, reducing power capacity, total antioxidant activity and DPPH radical scavenging activity. From the result on the various antioxidant activity tests, it was found that Dia-ion resin adsorbed fraction showed the highest value, followed by petroleum ether fraction, ethyl acetate fraction and chloroform fraction. Overall results of the antioxidant evaluation and various biological screening tests were found satisfactory and may encourage researcher to use this plant as a source of potent antioxidant food material as well as bioactive toxic compounds to be used in therapeutic drugs preparation.
\end{abstract}

Keywords: Phytochemistry; Antioxidant Activities; Alstonia scholaris; Chloroform

\section{Introduction}

Plant kingdom is a mysterious world of chemical compounds and mainly organic compounds. The nature abounds in organic compounds of every conceivable structural class. The cells of living organisms, plants, fungi, other animals are the sites of complex biosynthetics that result in the formation of many varieties of organic compounds; many of them are of great importance to mankind [1]. This is why the modern world is interestingly tending to go back to the pre- industrialized days, when the mankind used to depend on the plant kingdom for their food, shelter, medicine, and other essential commodities. This is perhaps, the only way to protect the ecological balance. The raw materials of the plant kingdom as mentioned above are directly or indirectly produced by the plants but are very seldom used by themselves and serve human beings in many ways. These are called the secondary metabolites or the natural products [2]. By the metabolic activity of plants produces not only the food materials so essential for sustenance of the life of animals but also certain other substances, such as alkaloids, vitamins, glycosides, toxalbumins, essential oils, resins, bitter principles etc. which are necessary for growth, maintenance and protection of life [3].

Many of these are essential for metabolic activities [4], many are medicines to human and animal life. Many of these are harmful to animal life, at least under certain conditions. Plants containing medicinal properties are commonly known as medicinal plants. The plants containing these principles are capable of acting deleteriously, are popularly known as poisonous plants. A poisonous plant is one which, as a whole or as a part thereof, under all or certain conditions, and in a manner and in amount likely to be taken or by brought into contact with an organism, 'will exert harmful effects or cause death either immediately or by reason of cumulative action of the toxic property, due to the presence of known or unknown chemical substances in it [5]. 
Although some of these plants are once poisons, medicines and food or fodder. The genus Alstonia belongs to the family Apocynaceae. It includes totally 43 species of which two species namely, A. scholaris (L.) R. Br. and A. venenata R. Br. are represented in South India [6]. These two species can be identified with their habits, shape and texture of the leaves, fruit size and papilla of the seeds The bark of Alstonia scholaris L is bitter, astringent, acrid, thermogenic, digestive, laxative, anthelmintic, febrifuge, antipyretic, depurative, galactogogue, stomachic, cardiotonic and tonic [7]. When these plants are used in herbal formulations, their botanical identity needs to be established beyond any ambiguity [8]. It has been found an important medicinal plant and addressed by scientist from various countries [9]. But in our country, this plant has not been studied in detail till now. Plant constituents are found different in quantity as well as in structure when collected from different sources.

\section{Methods and Materials}

All the reagents and chemicals were used for the presence work were purchased from THOMAS BAKER (MUMBAI, INDIA), BDH (ENGLAND), FLUKA (SWITZERLAND) and E. MERCK (GERMANY). Commercial alcohol (rectified spirit) and absolute alcohol were available from Carew and company, Darsana, Chuadanga. The Solvents used mainly in this work are benzene, acetone, tetrahydrofuran (THF), ethyl acetate, chloroform, n-hexane, petroleum ether, methanol, absolute alcohol, toluene etc. The solvents were dried and distilled when necessary.

During the present work solvents were purified priors to use by distillation at the boiling point at the respective solvents. Evaporation of solvents from the extracts and other solutions were carried out on a rotary evaporator under reduced pressure of bath temperature not exceeding $40{ }^{\circ} \mathrm{C}$. The purity of the compounds were tasted by analytical thin layer chromatography (TLC) on silica-gel plate and the Spots were made visible either by exposing it under UV lamp or iodine vapour or by spraying with the some suitable spray reagents, if it is not visible in the day light.

All evaporations were carried out under reduced pressure using a Rotary Vacuum Evaporator (rotavapour) on water bath temperature was not exceeding $40{ }^{\circ} \mathrm{C}$. Smaller volume of non-aqueous solvents were removed by keeping in open air. Crystallization was employed as a final purification process. The solvent was chosen in which the compound was least soluble. The compound was dissolved in a minimum volume at a solvent in hot condition and was left for crystallization. Sometimes mixture of solvents was also used. The Alstonia scholaris plant leaves were collected from the cultivated adjacent areas of BCSIR, Rajshahi. The collected leaves were washed with water.

$100 \mathrm{~g}$ of fresh leaves were taken for the determination of water content. Then the fresh leaves $(100 \mathrm{~g})$ were dried at room temperature and the dried leaves were weighted again and that was 37g. Therefore, the water content of the leaves of Alstonia scholaris was calculated below:

$$
\begin{aligned}
\backslash \text { Water content } & =\frac{(100-3) \times 100}{100} \\
& =63 \%
\end{aligned}
$$

Dried ground of Alstonia scholaris leaves $\left(\mathrm{W}_{1}=1.5802 \mathrm{~g}\right)$ were heated at $105^{\circ} \mathrm{C}$ until a constant weight was reached $\left(\mathrm{W}_{2}=1.4562 \mathrm{~g}\right)$ and the moisture content was determined.

Moisture content $=$

$=7.84 \%$

Dried ground Alstonia scholaris leaves contain 63\% water content and $7.84 \%$ moisture content. Thus, the dry matter of Alstonia scholaris given below:

Dry matter $=100-(63+7.84)=29.16 \%$

\section{Process of Extraction}

The collected materials were washed thoroughly in water, chopped, air dried for a week at $35-40{ }^{\circ} \mathrm{C}$ and pulverized in electric grinder. Dried ground leaves of Alstonia scholaris were exhaustively extracted with ethanol (EtOH, Analytical Grade, BDH Laboratory Supplies) in Soxhlet apparatus. The resulting juicy extract was filtered through Whatman paper No.1 and concentrated under reduced pressure at $45{ }^{\circ} \mathrm{C}$ using the Buchi Rotavapor R-200 to obtain a crude residue (23.5\%).The process have done for several time to increase the crude extract. Then water triturate part was collected from crude extract. The water triturate fraction was passed through a previously well packed Dia-ion resin column which has selectivity to collect only the phenolic group containing compounds. Then the materials, which were bound in resin column, collected by passing methanol solvent. Then Petroleum ether, Ethyl acetate and Chloroform solvents were passing through the residue respectively. Finally, Petroleum ether, Ethyl acetate and Chloroform triturate were collected.

Total phenolic content of different extractives of Alstonia scholaris were determined employing the method as described by involving Folin-Ciocalteu reagent as oxidizing agent and Gallic acid as standard [10].

\section{Determination of Total Antioxidant Activity}

1. $0.5 \mathrm{~mL}$ of plant extract or standard of different concentration solution was taken in a test tube.

2. $3 \mathrm{~mL}$ of reaction mixture containing $0.6 \mathrm{M}$ sulphuric acid, $28 \mathrm{mM}$ sodium phosphate and $1 \%$ ammonium molybdate was added into the test tube.

3. The test tube was incubated at $95{ }^{\circ} \mathrm{C}$ for 10 minutes to complete the reaction. 
4. Then the absorbance of the solution was measured at $695 \mathrm{~nm}$ using a spectrophotometer against blank after cooling at room temperature.

5. A typical blank solution contained $3 \mathrm{~mL}$ reaction mixture and the appropriate volume $(300 \mu \mathrm{L})$ of the same solvent used for the sample, and it was incubated under the same conditions as the rest of the sample's solution.

\section{Determination of Dpph Radical Scavenging Activity}

1. $2 \mathrm{~mL}$ of methanol solution of plant extract or standard at different concentration was taken in a test tube.

2. $3 \mathrm{~mL}$ of methanol solution of DPPH was added into the test tube.

3. The test tube was incubated at room temperature for 30 minutes in dark place to complete the reaction.

4. Then the absorbance of the solution was measured at
$517 \mathrm{~nm}$ using a spectrophotometer against blank.

5. A typical blank solution contained all reagents except plant extract or standard solution.

6. The percentage (\%) of scavenging was calculated from the following equation.

$\%$ of scavenging $=\left\{\left(A_{0}-A_{1}\right) / A_{0}\right\} \times 100$

Where,

$A_{0}$ is the absorbance of the control and

$\mathrm{A}_{1}$ is the absorbance of the extract/ standard.

Then $\%$ of scavenging were plotted against concentration and from the graph $\mathrm{IC}_{50}$ was calculated.

\section{Results \& Discussion}

Phytochemical screening of crude ethanol and four subfractions of the leaves of Alstonia scholaris Table 1.

Table 1: Phytochemical screening of crude ethanol and four sub-fractions of the leaves of Alstonia scholaris.

\begin{tabular}{|c|c|c|c|c|c|}
\hline $\begin{array}{l}\text { Phytochemical } \\
\text { constituents }\end{array}$ & Crude ethanol extract & $\begin{array}{l}\text { Petroleum ether } \\
\text { fraction }\end{array}$ & Chloroform fraction & Ethyl acetate fraction & $\begin{array}{l}\text { Dia-ion resin } \\
\text { adsorbed fraction }\end{array}$ \\
\hline Saponins & - & - & - & - & - \\
\hline Tannins & + & - & - & - & +++ \\
\hline Glycosides & + & + & - & - & ++ \\
\hline Steroids & ++ & ++ & + & + & ++ \\
\hline Alkaloids & +++ & - & ++ & + & +++ \\
\hline
\end{tabular}

Here, $+=$ Present in the mild amount,$++=$ Present in the moderate amount,$+++=$ Present in the large amount, $-=$ Not present.

\section{Total phenolic content}

Absorbance of Gallic acid at different concentrations for the determination of total phenolic content (Table 2).

Table 2: Absorbance of Gallic acid at different concentrations for the determination of total phenolic content.

\begin{tabular}{|c|c|c|c|c|}
\hline \multirow{2}{*}{ Concentration (mg/mL) } & \multicolumn{3}{|c|}{ Absorbance } & \multirow{2}{*}{ Absorbance Mean \pm STD } \\
\cline { 2 - 5 } & $\mathbf{a}$ & $\mathbf{b}$ & 0.077 & $0.077 \pm 0.001$ \\
\hline 10 & 0.076 & 0.078 & 0.182 & $0.178 \pm 0.004$ \\
\hline 20 & 0.175 & 0.178 & 0.371 & $0.372 \pm 0.003$ \\
\hline 40 & 0.375 & 0.369 & 0.713 & $0.714 \pm 0.004$ \\
\hline 80 & 0.711 & 0.718 & 1.415 & $1.403 \pm 0.013$ \\
\hline 160 & 1.405 & 1.389 & 2.818 & $2.802 \pm 0.014$ \\
\hline 320 & 2.791 & 2.797 & 2 & c \\
\hline
\end{tabular}

Determination of total phenolic content of different fractions of ethanolic extract of Alstonia scholaris (Table 3).

Table 3: Determination of total phenolic content of different fractions of ethanolic extract of Alstonia scholaris.

\begin{tabular}{|c|c|c|c|c|c|}
\hline Sample & No. of sample & $\begin{array}{c}\text { Concentration (mg/ } \\
\mathrm{mL})\end{array}$ & Absorbance & $\begin{array}{l}\text { GAE/g of dried } \\
\text { sample }\end{array}$ & $\begin{array}{c}\text { GAE } / g \text { of dried } \\
\text { sample Mean } \pm \text { STD }\end{array}$ \\
\hline \multirow{3}{*}{ Chloroform fraction } & 1 & 100 & 0.276 & 3.38 & $3.44 \pm 0.07$ \\
\hline & 2 & 100 & 0.288 & 3.52 & \\
\hline & 3 & 100 & 0.279 & 3.41 & \\
\hline
\end{tabular}




\begin{tabular}{|c|c|c|c|c|c|}
\hline \multirow{3}{*}{$\begin{array}{c}\text { Petroleum ether } \\
\text { fraction }\end{array}$} & 1 & 100 & 0.221 & 2.69 & $3.39 \pm 0.26$ \\
\cline { 2 - 6 } & 2 & 100 & 0.27 & 3.19 \\
\hline \multirow{3}{*}{\begin{tabular}{c} 
Ethyl acetate fraction \\
\cline { 2 - 6 }
\end{tabular}} & 3 & 100 & 0.261 & 5.48 & $5.67 \pm 0.20$ \\
\cline { 2 - 6 } & 1 & 100 & 0.444 & 5.66 \\
\hline \multirow{3}{*}{$\begin{array}{c}\text { Dia-ion resin adsorbed } \\
\text { fraction }\end{array}$} & 3 & 100 & 0.459 & 4.88 & 21.96 \\
\cline { 2 - 6 } & 1 & 100 & 1.763 & 22.03 \\
\hline
\end{tabular}

Total phenolic content of different fractions of Alstonia acetate fraction $(5.67 \pm 0.20 \mathrm{mg}$ Gallic acid/g of extract), Chloroform scholaris were shown in Table 5 and Figure 2. Among the fraction, fraction (3.44 $0.07 \mathrm{mg}$ Gallic acid/g of extract), and Petroleum the highest phenolic content was found in Dia-ion resin adsorbed ether fraction (3.39 $\pm 0.26 \mathrm{mg}$ Gallic acid/g of extract) (Figure 1). fraction (21.92 $\pm 0.13 \mathrm{mg}$ Gallic acid/g of extract), followed by ethyl

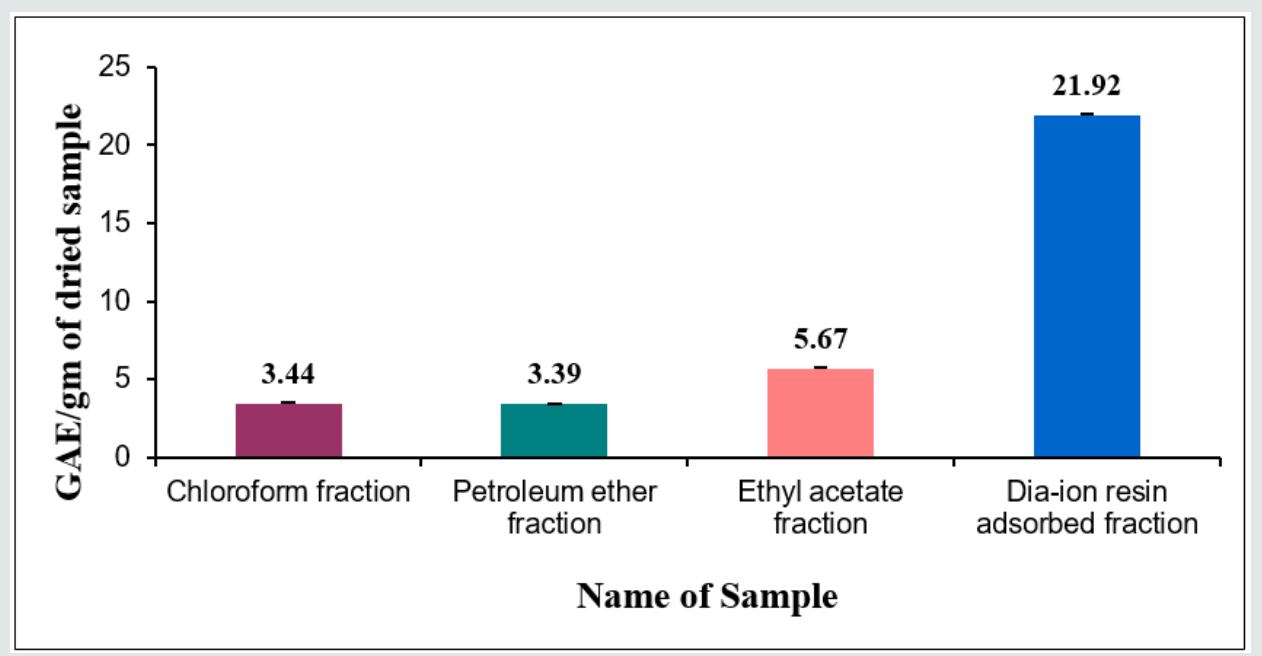

Figure 1: Total phenolic content (mg/g plant extract in gallic acid equivalent) of Alstonia scholaris.

\section{Total Flavonoid Content}

Absorbance of catechin at different concentration for the determination of total flavonoids (Table 4).

Table 4: Absorbance of catechin at different concentration for the determination of total flavonoids.

\begin{tabular}{|c|c|c|c|c|}
\hline \multirow{2}{*}{ Concentration (mg/mL) } & \multicolumn{3}{|c|}{ Absorbance } & \multirow{2}{*}{ Absorbance Mean \pm STD } \\
\hline & $\mathbf{a}$ & b & c & \\
\hline 31 & 0.245 & 0.231 & 0.243 & $0.239 \pm 0.007$ \\
\hline 62 & 0.369 & 0.379 & 0.376 & $0.375 \pm 0.005$ \\
\hline 125 & 0.675 & 0.679 & 0.688 & $0.681 \pm 0.007$ \\
\hline 250 & 1.311 & 1.297 & 1.289 & $1.299 \pm 0.011$ \\
\hline 500 & 2.423 & 2.432 & 2.441 & $2.432 \pm 0.009$ \\
\hline 320 & 2.791 & 2.797 & 2.818 & $2.802 \pm 0.014$ \\
\hline
\end{tabular}

Determination of total flavonoid content of different fractions of ethanolic extract of Alstonia scholaris (Table 5).

Table 5: Determination of total flavonoid content of different fractions of ethanolic extract of Alstonia scholaris.

\begin{tabular}{|c|c|c|c|c|}
\hline \multirow{2}{*}{ Sample } & No. of sample & $\begin{array}{c}\text { Concentration (mg/ } \\
\mathbf{m L}\end{array}$ & $\begin{array}{c}\text { Cat.E /g of dried } \\
\text { sample }\end{array}$ & $\begin{array}{c}\text { Cat.E/g of dried } \\
\text { sample Mean } \mathbf{\pm S T D}\end{array}$ \\
\hline \multirow{3}{*}{ Chloroform fraction } & 1 & 250 & 0.877 & 9.78 \\
\cline { 2 - 5 } & 2 & 250 & 0.901 & 10.08 \\
\hline
\end{tabular}




\begin{tabular}{|c|c|c|c|c|c|}
\hline \multirow{3}{*}{$\begin{array}{c}\text { Petroleum ether } \\
\text { fraction }\end{array}$} & 1 & 250 & 0.979 & 11.05 & $10.91 \pm 0.17$ \\
\cline { 2 - 6 } & 2 & 250 & 0.953 & 10.72 & \\
\hline \multirow{3}{*}{ Ethyl acetate fraction } & 3 & 250 & 0.972 & 10.96 & 9.41 \\
\cline { 2 - 6 } & 1 & 250 & 0.848 & 9.9 & \\
\hline \multirow{3}{*}{$\begin{array}{c}\text { Dia-ion resin adsorbed } \\
\text { fraction }\end{array}$} & 2 & 250 & 0.807 & 9.62 & $16.61 \pm 0.06$ \\
\cline { 2 - 6 } & 1 & 250 & 1.42 & 16.56 & \\
\hline
\end{tabular}

Here, Cat. (Catechin) and Cat. E (Catechin Equivalent).

Total flavonoid content of different fractions of Alstonia scholaris were show in Table 7 and Figure 2. Among the fraction, the highest total flavonoid content was found in Dia-ion resin adsorbed fraction (16.61 $\pm 0.06 \mathrm{mg}$ Catechin/g of extract), followed

by Petroleum ether fraction $(10.91 \pm 0.17 \mathrm{mg}$ Catechin/g of extract), Chloroform fraction $(9.96 \pm 0.16 \mathrm{mg}$ Catechin/g of extract), and Ethyl acetate fraction (9.31 $\pm 0.37 \mathrm{mg}$ Catechin/g of extract) (Figure 2).

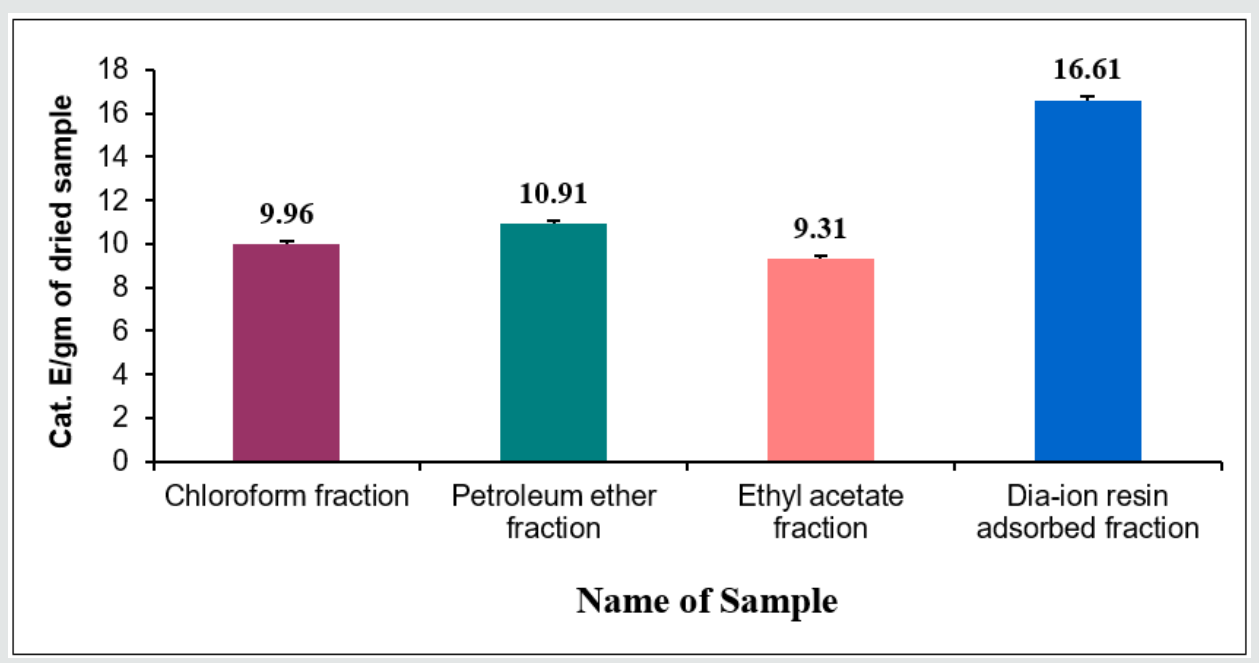

Figure 2: Total flavonoid content (mg/g plant extract in catechin equivalent) of Alstonia scholaris.

\section{Reducing Power Capacity Content}

Reducing power capacity of different fractions of ethanolic extract of Alstonia scholaris and Ascorbic acid (standard) at different concentrations (Table 6).

Table 6: Reducing power capacity of different fractions of ethanolic extract of Alstonia scholaris and Ascorbic acid (standard) at different concentrations.

\begin{tabular}{|c|c|c|c|c|c|}
\hline \multirow{2}{*}{ Name of sample } & \multirow{2}{*}{$\begin{array}{c}\text { Concentration (mg/ } \\
\text { mL) }\end{array}$} & \multicolumn{3}{|c|}{ Absorbance } & \multirow{2}{*}{$\begin{array}{c}\text { Absorbance } \\
\text { Mean } \pm \text { STD }\end{array}$} \\
\hline & & $\mathbf{a}$ & $\mathbf{b}$ & c & \\
\hline \multirow{5}{*}{$\begin{array}{l}\text { Ascorbic acid } \\
\text { (Standard) }\end{array}$} & 5 & 1.088 & 1.225 & 1.069 & $1.127 \pm 0.039$ \\
\hline & 10 & 1.912 & 1.874 & 1.931 & $1.905 \pm 0.007$ \\
\hline & 20 & 2.629 & 2.629 & 2.312 & $2.523 \pm 0.106$ \\
\hline & 40 & 2.677 & 2.679 & 2.672 & $2.676 \pm 0.001$ \\
\hline & 80 & 2.829 & 2.831 & 2.852 & $2.837 \pm 0.008$ \\
\hline \multirow{5}{*}{ Chloroform fraction } & 5 & 0.081 & 0.076 & 0.088 & $0.081 \pm 0.006$ \\
\hline & 10 & 0.207 & 0.216 & 0.209 & $0.210 \pm 0.004$ \\
\hline & 20 & 0.379 & 0.362 & 0.358 & $0.366 \pm 0.011$ \\
\hline & 40 & 0.805 & 0.822 & 0.835 & $0.820 \pm 0.015$ \\
\hline & 80 & 1.506 & 1.487 & 1.468 & $1.487 \pm 0.019$ \\
\hline
\end{tabular}




\begin{tabular}{|c|c|c|c|c|c|}
\hline \multirow{5}{*}{$\begin{array}{l}\text { Petroleum ether } \\
\text { fraction }\end{array}$} & 5 & 0.09 & 0.096 & 0.088 & $0.091 \pm 0.004$ \\
\hline & 10 & 0.137 & 0.153 & 0.132 & $0.140 \pm 0.010$ \\
\hline & 20 & 0.24 & 0.232 & 0.248 & $0.240 \pm 0.008$ \\
\hline & 40 & 0.47 & 0.485 & 0.489 & $0.481 \pm 0.010$ \\
\hline & 80 & 0.843 & 0.835 & 0.832 & $0.836 \pm 0.005$ \\
\hline \multirow{5}{*}{ Ethyl acetate fraction } & 5 & 0.064 & 0.087 & 0.088 & $0.079 \pm 0.013$ \\
\hline & 10 & 0.112 & 0.136 & 0.123 & $0.123 \pm 0.012$ \\
\hline & 20 & 0.245 & 0.233 & 0.261 & $0.246 \pm 0.014$ \\
\hline & 40 & 0.537 & 0.539 & 0.545 & $0.540 \pm 0.004$ \\
\hline & 80 & 0.995 & 0.977 & 1.023 & $0.998 \pm 0.023$ \\
\hline \multirow{5}{*}{$\begin{array}{l}\text { Dia-ion resin adsorbed } \\
\text { fraction }\end{array}$} & 5 & 0.226 & 0.215 & 0.211 & $0.217 \pm 0.007$ \\
\hline & 10 & 0.732 & 0.756 & 0.766 & $0.751 \pm 0.017$ \\
\hline & 20 & 1.629 & 1.625 & 1.61 & $1.621 \pm 0.010$ \\
\hline & 40 & 2.118 & 2.225 & 2.321 & $2.221 \pm 0.101$ \\
\hline & 80 & 2.463 & 2.474 & 2.467 & $2.468 \pm 0.006$ \\
\hline
\end{tabular}

The iron reducing capacity of the four different fractions of Alstonia scholaris extract such as petroleum ether fraction, chloroform fraction ethyl acetate and Dia-ion resin adsorbed fraction have been investigated. Among the four different extractives Dia-ion resin adsorbed fraction showed the highest iron reducing capacity with absorbance of $2.468 \pm 0.006$ at $80 \mu \mathrm{g} / \mathrm{mL}$ concentration, followed by Chloroform fraction with absorbance $1.487 \pm 0.019$ at $80 \mu \mathrm{g} / \mathrm{mL}$, while Ethyl acetate fraction showed iron reducing capacity with absorbance of $0.998 \pm 0.023$ at $80 \mu \mathrm{g} / \mathrm{mL}$ and Petroleum ether fraction showed the iron reducing capacity with absorbance $0.836 \pm 0.005$ at $80 \mu \mathrm{g} / \mathrm{mL}$ (Figure 3).

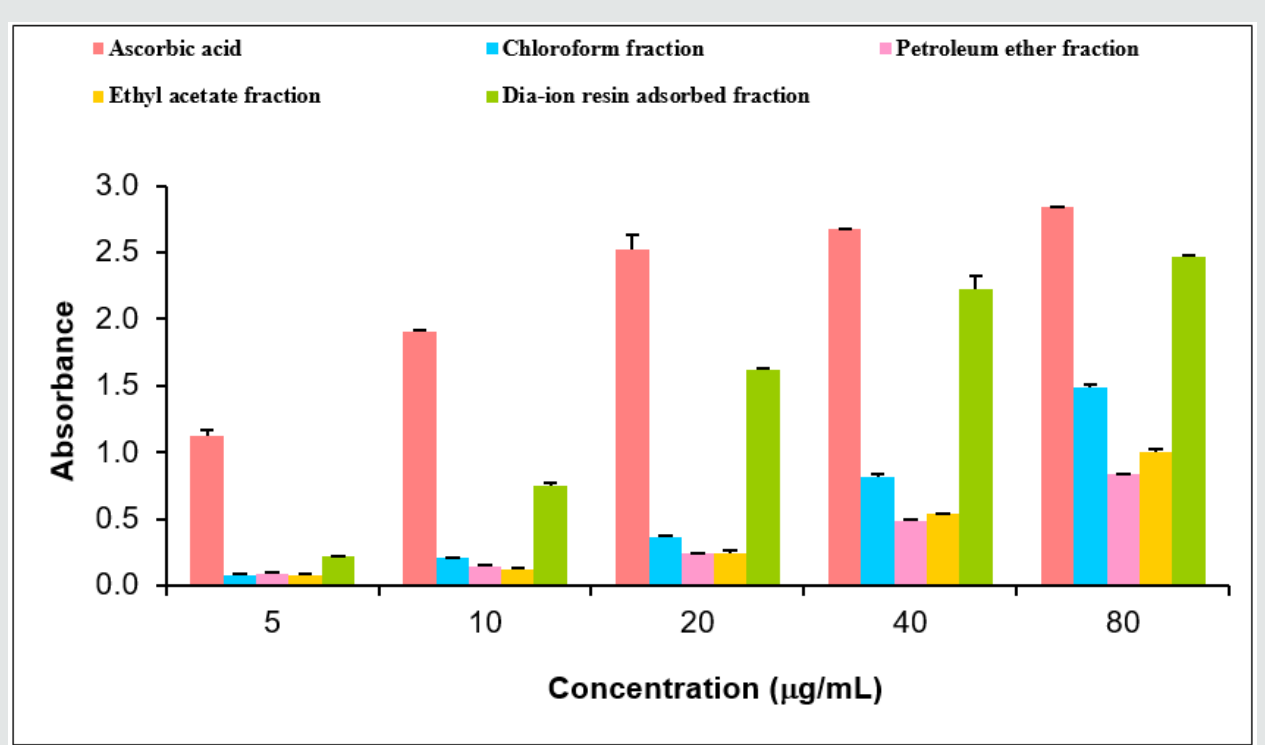

Figure 3: Reducing power capacity of different fractions of ethanolic extract of Alstonia scholaris and Ascorbic acid (Standard).

The reducing power of the different extractives and standard exhibited the following order:

Ascorbic acid $>$ DRAF $>$ CLF $>$ EAF $>$ PEF

\section{Total Antioxidant Activity}

Total antioxidant activity of different fractions of Alstonia scholaris and Ascorbic acid (standard) at different concentrations (Table 7). 
Table 7: Total antioxidant activity of different fractions of Alstonia scholaris and Ascorbic acid (standard) at different concentrations.

\begin{tabular}{|c|c|c|c|c|c|}
\hline \multirow{2}{*}{ Name of sample } & \multirow{2}{*}{$\begin{array}{l}\text { Concentration } \\
(\mathrm{mg} / \mathrm{mL})\end{array}$} & \multicolumn{3}{|c|}{ Absorbance } & \multirow{2}{*}{$\begin{array}{c}\text { Absorbance } \\
\text { Mean } \pm \text { STD }\end{array}$} \\
\hline & & $\mathbf{a}$ & b & c & \\
\hline \multirow{5}{*}{$\begin{array}{l}\text { Ascorbic acid } \\
\text { (standard) }\end{array}$} & 10 & 0.175 & 0.166 & 0.182 & $0.174 \pm 0.008$ \\
\hline & 20 & 0.452 & 0.478 & 0.431 & $0.453 \pm 0.024$ \\
\hline & 40 & 0.953 & 0.933 & 1.008 & $0.964 \pm 0.039$ \\
\hline & 80 & 2.122 & 2.193 & 2.167 & $2.160 \pm 0.036$ \\
\hline & 100 & 3.192 & 3.202 & 3.38 & $3.258 \pm 0.106$ \\
\hline \multirow{5}{*}{$\begin{array}{l}\text { Petroleum Ether } \\
\text { Fraction }\end{array}$} & 10 & 0.062 & 0.076 & 0.068 & $0.068 \pm 0.007$ \\
\hline & 20 & 0.233 & 0.234 & 0.25 & $0.239 \pm 0.009$ \\
\hline & 40 & 0.413 & 0.425 & 0.44 & $0.426 \pm 0.013$ \\
\hline & 80 & 0.707 & 0.718 & 0.721 & $0.715 \pm 0.007$ \\
\hline & 100 & 0.939 & 1.005 & 0.978 & $0.974 \pm 0.033$ \\
\hline \multirow{5}{*}{ Ethyl Acetate fraction } & 10 & 0.119 & 0.128 & 0.132 & $0.126 \pm 0.006$ \\
\hline & 20 & 0.536 & 0.527 & 0.548 & $0.537 \pm 0.010$ \\
\hline & 40 & 0.661 & 0.678 & 0.656 & $0.665 \pm 0.011$ \\
\hline & 80 & 0.743 & 0.723 & 0.737 & $0.734 \pm 0.010$ \\
\hline & 100 & 0.977 & 0.943 & 0.923 & $0.947 \pm 0.027$ \\
\hline \multirow{5}{*}{ Chloroform fraction } & 10 & 0.009 & 0.008 & 0.009 & $0.008 \pm 0.001$ \\
\hline & 20 & 0.149 & 0.173 & 0.169 & $0.163 \pm 0.012$ \\
\hline & 40 & 0.268 & 0.259 & 0.255 & $0.260 \pm 0.007$ \\
\hline & 80 & 0.489 & 0.496 & 0.503 & $0.496 \pm 0.007$ \\
\hline & 100 & 0.595 & 0.611 & 0.623 & $0.609 \pm 0.014$ \\
\hline \multirow{5}{*}{$\begin{array}{l}\text { Dia-ion resin adsorbed } \\
\text { fraction }\end{array}$} & 10 & 0.111 & 0.123 & 0.132 & $0.122 \pm 0.010$ \\
\hline & 20 & 0.238 & 0.254 & 0.243 & $0.245 \pm 0.008$ \\
\hline & 40 & 0.44 & 0.464 & 0.452 & $0.452 \pm 0.012$ \\
\hline & 80 & 0.875 & 0.889 & 0.893 & $0.885 \pm 0.009$ \\
\hline & 100 & 1.065 & 1.045 & 1.038 & $1.049 \pm 0.014$ \\
\hline
\end{tabular}

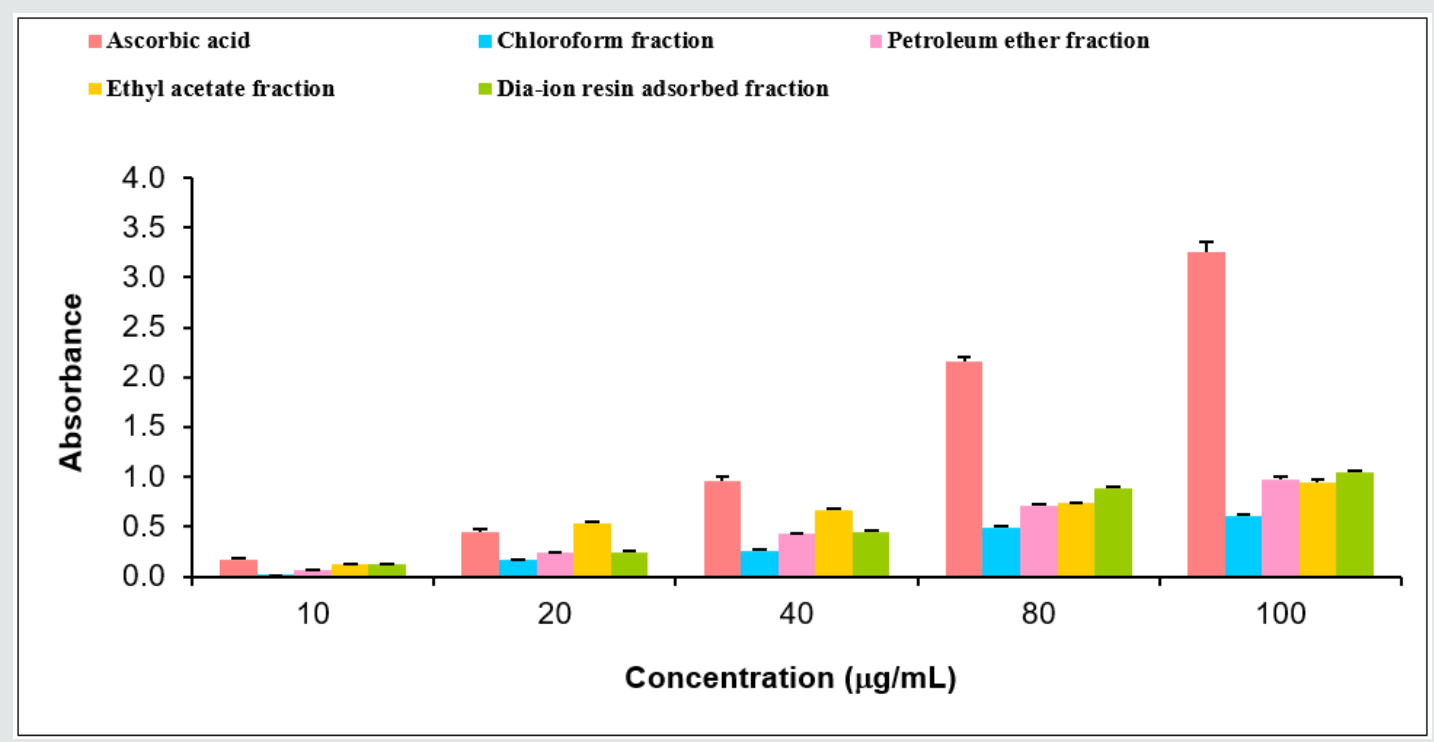

Figure 4: Total antioxidant activity of different fractions of ethanolic extract of Alstonia scholaris and Ascorbic acid (Standard). 
Total antioxidant activity of different fractions of ethanolic extract of Alstonia scholaris such as Dia-ion resin adsorbed fraction, chloroform fraction, Ethyl acetate fraction and petroleum ether fraction were investigated. Among the fractions, Dia-ion resin adsorbed fraction showed the highest total antioxidant activity with absorbance $1.049 \pm 0.014$ at $100 \mu \mathrm{g} / \mathrm{mL}$. Whereas the Petroleum ether and Ethyl acetate fraction showed the absorbance $0.974 \pm 0.033$ at $100 \mu \mathrm{g} / \mathrm{mL}$ and $0.947 \pm 0.027$ at $100 \mu \mathrm{g} /$ $\mathrm{mL}$ respectively. Chloroform fraction showed the lowest total antioxidant activity with absorbance $0.609 \pm 0.014$ at $100 \mu \mathrm{g} / \mathrm{mL}$ concentration (Figure 4).

The total antioxidant activity of different extractives and standard exhibited the following order:

$$
\text { Ascorbic acid }>\text { DRAF }>\text { PEF }>\text { EAF }>\text { CLF }
$$

\section{DPPH Radical Scavenging Activity}

DPPH radial scavenging activity of different fractions of ethanolic extract of Alstonia scholaris and BHT (standard) at different concentrations (Table 8).

Table 8: DPPH radial scavenging activity of different fractions of ethanolic extract of Alstonia scholaris and BHT (standard) at different concentrations.

\begin{tabular}{|c|c|c|c|c|c|c|}
\hline \multirow{2}{*}{ Name of sample } & \multirow{2}{*}{$\begin{array}{c}\text { Concentration } \\
(\mathrm{mg} / \mathrm{mL})\end{array}$} & \multicolumn{3}{|c|}{$\%$ of Scavenging } & \multirow{2}{*}{$\begin{array}{c}\% \text { of Scavenging } \\
\text { Mean } \pm \text { STD }\end{array}$} & \multirow{2}{*}{$\mathrm{IC}_{50}(\mathrm{mg} / \mathrm{mL})$} \\
\hline & & a & b & c & & \\
\hline BHT & 25 & 36.45 & 36.37 & 36.71 & $36.51 \pm 0.18$ & 37.87 \\
\hline \multirow{4}{*}{ (Standard) } & 50 & 63.69 & 63.97 & 63.67 & $63.77 \pm 0.17$ & \\
\hline & 100 & 88.5 & 88.73 & 88.92 & $88.71 \pm 0.21$ & \\
\hline & 150 & 95.83 & 95.89 & 95.65 & $95.79 \pm 0.12$ & \\
\hline & 200 & 96.35 & 96.57 & 96.27 & $96.39 \pm 0.15$ & \\
\hline \multirow{5}{*}{$\begin{array}{l}\text { Chloroform } \\
\text { fraction }\end{array}$} & 25 & 27.33 & 27.57 & 28.12 & $27.67 \pm 0.40$ & 70.3 \\
\hline & 50 & 40.78 & 41.54 & 41.77 & $41.36 \pm 0.52$ & \\
\hline & 100 & 63.98 & 64.32 & 63.78 & $64.02 \pm 0.27$ & \\
\hline & 150 & 82.21 & 82.33 & 81.99 & $82.17 \pm 0.17$ & \\
\hline & 200 & 80.51 & 80.57 & 80.69 & $80.59 \pm 0.09$ & \\
\hline \multirow{5}{*}{$\begin{array}{l}\text { Petroleum ether } \\
\text { fraction }\end{array}$} & 25 & 32.86 & 33.22 & 32.72 & $32.93 \pm 0.26$ & 113.63 \\
\hline & 50 & 40.57 & 40.66 & 40.34 & $40.52 \pm 0.16$ & \\
\hline & 100 & 47.39 & 47.87 & 47.89 & $47.71 \pm 0.28$ & \\
\hline & 150 & 58.9 & 58.77 & 58.33 & $58.66 \pm 0.29$ & \\
\hline & 200 & 71.54 & 71.07 & 70.56 & $71.05 \pm 0.49$ & \\
\hline \multirow{5}{*}{$\begin{array}{l}\text { Ethyl acetate } \\
\text { fraction }\end{array}$} & 25 & 45.57 & 44.43 & 44.98 & $44.99 \pm 0.57$ & 40.9 \\
\hline & 50 & 54.21 & 53.76 & 53.34 & $53.77 \pm 0.44$ & \\
\hline & 100 & 76.89 & 77.55 & 76.22 & $76.88 \pm 0.66$ & \\
\hline & 150 & 86.77 & 86.43 & 86.64 & $86.61 \pm 0.17$ & \\
\hline & 200 & 87.99 & 88.45 & 88.26 & $88.23 \pm 0.23$ & \\
\hline \multirow{5}{*}{$\begin{array}{l}\text { Dia-ion resin } \\
\text { adsorbed fraction }\end{array}$} & 25 & 51.01 & 51.21 & 51.43 & $51.21 \pm 0.21$ & 24.9 \\
\hline & 50 & 52.78 & 52.33 & 52.45 & $52.52 \pm 0.23$ & \\
\hline & 100 & 53.55 & 53.65 & 53.73 & $53.64 \pm 0.09$ & \\
\hline & 150 & 54.01 & 54.11 & 54.24 & $54.12 \pm 0.12$ & \\
\hline & 200 & 55.76 & 56.08 & 56.13 & $55.99 \pm 0.20$ & \\
\hline
\end{tabular}

Among the fractions of the extract, highest DPPH radical scavenging activity was found in Dia-ion resin adsorbed fraction having $\mathrm{IC}_{50}$ value $24.90 \mu \mathrm{g} / \mathrm{mL}$. On the other hand, chloroform fraction showed DPPH radical scavenging activity with $\mathrm{IC}_{50}$ value $73.30 \mu \mathrm{g} / \mathrm{mL}$, followed by ethyl acetate fraction with $\mathrm{IC}_{50}$ value $40.90 \mu \mathrm{g} / \mathrm{mL}$ and petroleum ether fraction showed DPPH radical scavenging activity with $\mathrm{IC}_{50}$ value $113.63 \mu \mathrm{g} / \mathrm{mL}$.

From the above results, we can conclude that, Dia-ion resin adsorbed fraction shows the highest activity in Total phenolic content, Total flavonoid content, Total antioxidant and DPPH radical scavenging (Figure 5 \& 6). 


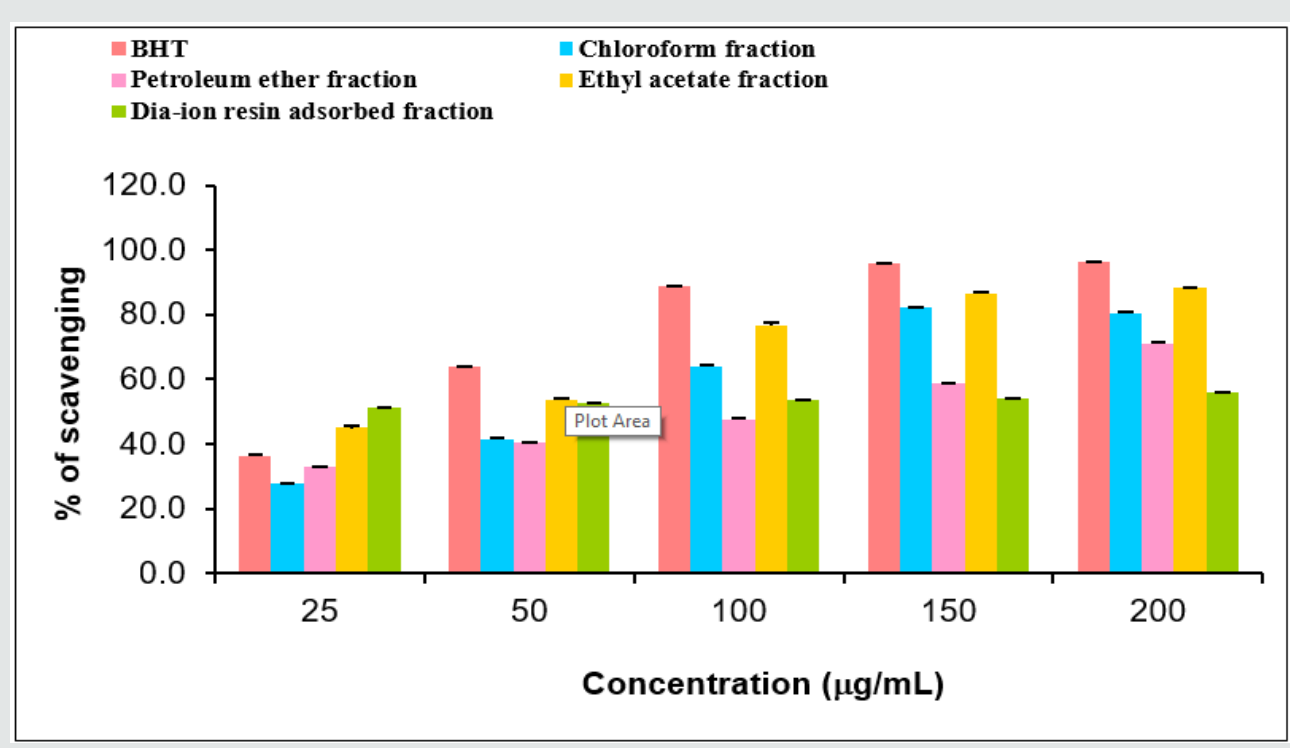

Figure 5: DPPH radical scavenging activity of different fractions of ethanolic extract of Alstonia scholaris and BHT (standard).

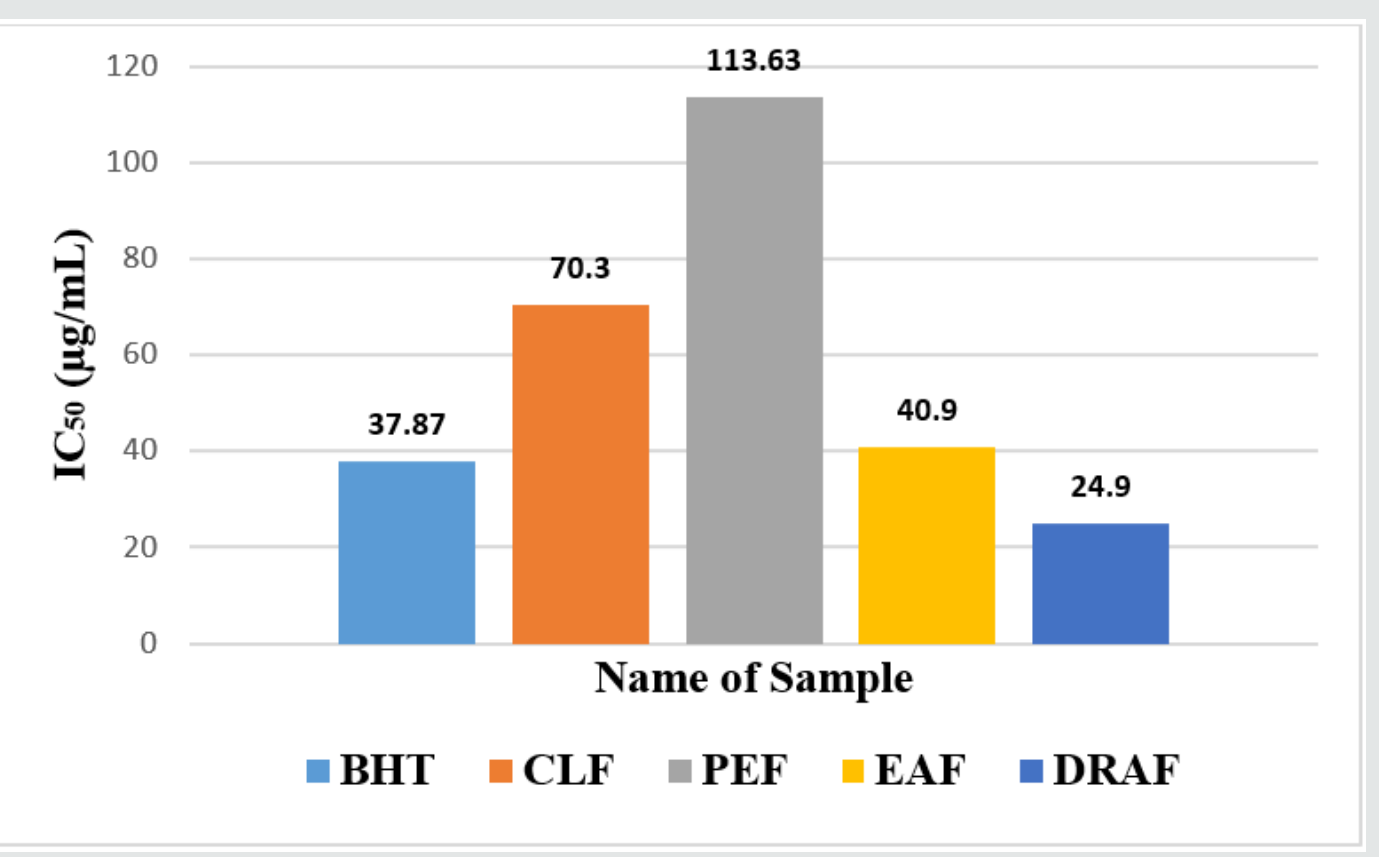

Figure 6: $\mathrm{IC}_{50}(\mu \mathrm{g} / \mathrm{ml})$ of different extractives of Alstonia scholaris for free redical scavenging activity by DPPH radical.

\section{Conclusion}

The present study investigated the plant Alstonia Scholaris for antioxidant evaluation and biological activity of different extractives. For this purpose, total phenolic content, total flavonoid content, total antioxidant, DPPH radical scavenging activity tests were performed with four different fractions of the plant. From the results of the antioxidant activity test, it is clearly seen that Diaion resin adsorbed fraction had the highest antioxidant activity. Considering the antioxidant activities assay of $A$. scholaris, it can be deduced that this plant contains useful potent bioactive toxic compounds, which can be harnessed and purified into useful therapeutic drugs. However, further studies are warranted for more extensive antioxidant and biological evaluations to elucidate before bringing them into commercial use.

\section{References}

1. Jagetia GC and Baliga MS. The effect of seasonal variation on the antineoplastic activity of Alstoniascholaris R. Br. in HeLa cells. Journal of Ethnopharmacology; 96: 37-42.2005.

2. A. H. M.M. Rahman, M. Anisuzzaman, S. A. Haider, Ferdous Ahmed, A. K. M. Rafiul Islam and A. T. M. Naderuzzaman. Research Journal of Agriculture and Biological Science, 4(1): 70-74.2008.

3. Khan AV, Parveen G, Alam MM, Singh VK. Ethnomedicinal uses of Neem in rural areas of Uttar Pradesh, India. Ethnomed and Pharmacog, (Sci. Tech. Pub. USA). II Rec. Prog. Med. Plants pp.7:319-326. 2002. 
4. Shan Zhao, Jie Yuan Liu, Si Yu Chen, Ling Ling Shi, Yu Jun Liu and Chao Ma. Antioxidant Potential of Polyphenols and Tannins from Burs of CastaneamollissimaBlume. Molecules. 16, 8590-8600. 2011.

5. Khyade, M. S. and Vaikos, N. P. 'phytochemical and antibacterial properties of leaves of Alstoniascholaris R. Br'. African journal of Biotechnology; 8(22):6434-6436.2009.

6. Shan Zhao, Jie Yuan Liu, Si Yu Chen, Ling Ling Shi, Yu Jun Liu and Chao Ma. Antioxidant Potential of Polyphenols and Tannins from Burs of CastaneamollissimaBlume. Molecules. 16, 8590-8600. 2011.

7. ShaileshRana, C. Bhatt, N. Kanaki and M. Zaveri. Advanced Research in Pharmaceuticals and Biologicals; Vol 2 (3): ISSN 2250-0774:p 290-295. 2012.
8. Mabberley, D.J., The Plant-Book. A portable dictionary of the vascular plants. Cambridge University Press. P. 267. 2005.

9. Khyade, M. S. and Vaikos, N. P. 'phytochemical and antibacterial properties of leaves of Alstoniascholaris R. Br'. African journal of Biotechnology; 8(22):6434-6436. 2009.

10. Karthishwaran K, Mirunalini S, Dhamodharanand G. Arulmozhi V. Jr of biological sciences; 10(3):242-246. 2010

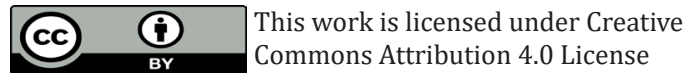

To Submit Your Article Click Here:

Submit Article

DOI: 10.32474/OAJCAM.2020.02.000140 